\title{
Vaktaalrubriek
}

\section{Nuwe terme in chemie en verwante gebiede}

\author{
W. van Z. de Villiers \\ Departement Stralingstegnologie, Atoomenergiekorporasie, Posbus 582, Pretoria, 0001
}

Die onlangse uitnodiging' aan gebruikers van Afrikaanse chemieterminologie om nuwe terme vir oorweging voor te lê en om by te dra tot die vul van moontlike leemtes in die Nuwe Chemiewoordeboek ${ }^{2}$ het dadelik reaksie uitgelok. Met hierdie bydrae word enkele sake vir bespreking aangebied, en belangstellendes word genooi om hul mening te gee sodat verseker kan word dat bruikbare terme geskep en gebruikersvriendelike terminologie beskikbaar gestel word. Hoewel onderstaande voorbeelde grootliks op die chemie afgestem is, is daar sekerlik heelwat raakvlakke met ander vakgebiede in die natuurwetenskap, mediese wetenskap, ingenieurswese en tegnologie.

\section{AFKORTINGS}

\begin{abstract}
Afkortings wat $g \boldsymbol{e}$ - bevat
Geen vaste taalreël, soos byvoorbeeld deur die Taalkommissie van die SA Akademie vir Wetenskap en Kuns neergelê, bestaan m.b.t. die afkorting van terme waarin voltooide deelwoorde voorkom nie. In 1984 het die Suid-Afrikaanse Buro vir Standaarde wel verteenwoordigers van ' $n$ aantal van die grootste gebruikers/ skeppers van natuurwetenskaplike en tegnologiese vakterme in Afrikaans byeengebring om oor 'n afkortpraktyk vir vakterme te besin. ${ }^{3}$ Daar is ooreengekom dat die voorvoegsel $g e$ - verkieslik geïgnoreer moet word by die afkorting van terme waarin voltooide deelwoorde voorkom. In sulke gevalle moet die stamwerkwoord in ag geneem word. Hierdie formulering kon nie afgedwing word nie, maar was bloot 'n poging tot standaardisasie.

In die Nuwe Chemiewoordeboek kom byvoorbeeld die volgende voor:
\end{abstract}

butylated hydroxyanisole : gebutileerde hidroksianisool (gebruiklike afkorting $B H A$ )

fluorinated ethylene propylene : gefluoreerde etileenpropileen $(F E P)$

hexagonal close-packed : heksagonaal dig gepak (HDP) protein-bound iodine : proteïengebinde jodium $(P B I)$ stereospecifically numbered : stereospesifiek genommer $(s n)$

inductively coupled plasma : induktief gekoppelde plasma $(I K P)$

Laasgenoemde afkorting vind oënskynlik bitter min inslag, aangesien $I G P$ algemeen gebruik word. Die rede daarvoor is moeilik om te bepaal; dit het bloot "natuurlik" gebeur. Hier ontstaan nou 'n paar vrae:

- Wat is die relatiewe gebruiksfrekwensie van IKP en IGP?

- Indien laasgenoemde grootliks verkies word, moet dit dan deurgaans aanbeveel en die gebruik van IKP ontmoedig word? As konsekwentheid die maatstaf is, is dit sekerlik ongewens dat die twee afkortings lukraak gebruik word. (Aan die ander kant: as konsekwentheid allesoorheersend is, behoort daar glad nie afgewyk te word van die aanbe- veling dat die stamwerkwoord in bogenoemde gevalle die deurslag moet gee nie - dus $I K P$.)

- Moet die keuse hier (as 'n spesiale geval) nie bloot aan die gebruikers oorgelaat word nie?

In dieselfde verband is dit interessant om te let op die volgende voorbeelde uit die Afrikaanse woordelys en spelreël $l s^{4}$ (AWS), waarin - $g$ - of - $G$ - deurgaans in die afkorting opgeneem is:

eg. : eersgenoemde

GKTV : geslotekringtelevisie

GR : Geoktrooieerde Rekenmeester

GWTV : Geassosieerde Wetenskaplike en Tegniese Verenigings

NGK : Nederduitse Gereformeerde Kerk

w.g. : was geteken

RGO : rekenaargesteunde onderrig

Om sake verder te bemoeilik, gebruik twee rekenaarwoordeboeke in laasgenoemde geval verskillende uitgangspunte, nl. $R S O$ en $R S L$ vir onderskeidelik rekenaargesteunde onderrig en rekenaargesteunde leer deur Coetzee, Du Plooy en Cluver, ${ }^{5}$ maar $R G O$ en $R G L$ deur Dodds en Grobbelaar! ${ }^{6}$

\section{Afkortings in spektroskopie en analitiese wetenskap}

Die volgende word voorgestel vir byvoeging tot die Nuwe Chemiewoordeboek en opname in die Nasionale Termbank:

AAS : atoomabsorpsiespektrometrie

ETA : elektrotermiese atomisering

AFS : atoomfluoressensiespektrometrie

AES : atoomemissiespektrometrie

In laasgenoemde geval word voorkeur deesdae aan optieseemissiespektrometrie (OES) gegee. Dit kan ook verwarring met $A E S$ vir Auger-elektronspektroskopie uitskakel.

RSA : relatiewe standaardafwyking.

Potensiële verwarring met Republiek van Suid-Afrika behoort nie hier te ontstaan nie. Trouens, daar is verskeie voorbeelde in die AWS waar een afkorting meer as een betekenis in verskillende kontekste kan hê, byvoorbeeld $R S A$ ook vir (die gewese) Radio Suid-Afrika!

Die gebruik van die terme dele per miljoen en dele per biljoen, en die behoefte om dit af te kort, skep groot probleme. Dit word dikwels verkeerd gebruik in die aanduiding van die konsentrasie van spesies in die gas- en vloeistoffase, terwyl 'n biljoen ook nie vir almal dieselfde betekenis het nie. Die Internasionale Unie vir Suiwer en Toegepaste Chemie (in die omgang beter bekend volgens die Engelse afkorting IUPAC) beveel ook nie die gebruik van die genoemde terme aan nie. Die gebruiklike afkortings $d p m$ (en nie $D P M$ of $d / m$ soos in die AWS aangedui nie) en $d p b$ moet 
dus ontmoedig word ten gunste van die gebruik van SIeenhede. Om die waarheid te sê, in die hersiene Fisikawoordeboek waaraan tans gewerk word, verskyn dit soos volg:?

$$
\begin{aligned}
& \text { dpm <kyk dele per miljoen> en } \\
& \text { ppm <see parts per million> }
\end{aligned}
$$

Hierdie vorm van inskrywing dui aan dat die eerste gedeelte (buite die skerp hakies) ' $n$ ongewenste term is.

\section{MOONTLIKE BYVOEGINGS TOT DIE NUWE CHE- MIEWOORDEBOEK}

\section{Samestellings met torch}

\author{
torch : brander \\ ICP torch : IKP-brander (IGP-brander?) \\ plasma torch : plasmabrander
}

Hierdie terme word gereeld gebruik m.b.t. induktief gekoppelde plasmas, asook plasmategnologie in die algemeen. Is daar moontlik ander vertalings wat in ander dissiplines gebruik word?

\section{Samestellings met standard}

Die Nuwe Chemiewoordeboek vertaal alle terme wat standard .... bevat, met standaard ...., behalwe in die volgende geval:

standard conditions (normal conditions) : normale toestande

normal conditions (standard conditions) : normale toestande

Dit was vroeër gebruiklik om standard temperature and pressure en normal temperature and pressure as sinonieme te beskou. Dit is egter nie meer korrek nie en word byvoorbeeld in die hersiene Fisikawoordeboek aangegee as

$$
\text { normal .... <see standard ....> }
$$

Die inskrywings in die Nuwe Chemiewoordeboek moet dus deur die volgende vervang word:

standard conditions : standaardtoestande normal conditions <see standard conditions>

Soortgelyke inskrywings in die Afrikaanse deel sal dan wel meebring dat die volgende verskyn:

standaardtoestande : standard conditions standaardtoestand : standard state

Gaan dit nie verwarring meebring nie?

Voorafgaande stem dan ook ooreen met die volgende in die Kernbedryfwoordeboek:8

standard atmosphere : standaardatmosfeer standard temperature and pressure (STP) : standaardtemperatuur en -druk, STD permeability : I. deurlatendheid (bv. van membraan);

$$
\text { 2. deurtrekbaarheid }
$$

permeate : deurtrek, deurvloei

permeation : deurtrekking, deurvloeiing

Terblanche 9 gee die volgende:

permeability : permeabiliteit, deurtrekbaarheid permeate : deurtrek, deurvloei permeation : magnetiese digtheid, deurtrekking

In die Kernbedryfwoordeboek word die volgende gegee:

permeability : deurlatendheid, deurtrekbaarheid permeable membrane : deurlatende membraan permeate n. : permeaat permeate v. : deurtrek

Die gebruik van permeaat as selfstandige naamwoord is redelik algemeen in membraantegnologie. Dit het meegebring dat die werkwoord permeëer dikwels gebruik word, eerder as deurtrek of deurvloei. Beteken dit dat 'n derde sinoniem (permeëer) asook permeaat as selfstandige naamwoord in die Nuwe Chemiewoordeboek bygevoeg moet word?

\section{Afleidings van nebulise}

Die huidige inskrywings in die Nuwe Chemiewoordeboek gee vernewel en newelaar aan vir onderskeidelik nebulise en nebuliser, terwyl Terblanche nebuliser met verstuiwer en newelaar as sinonieme vertaal. In analitiese chemie (bv. by AAS) word afleidings van verstuif algemeen gebruik, wat meebring dat die volgende inskrywings in die Nuwe Chemiewoordeboek oorweeg behoort te word:

nebulisation efficiency : verstuiwingsdoeltreffendheid, vernewelingsdoeltreffendheid

nebulise : verstuif, vernewel

nebuliser : verstuiwer, vernewelaar

nebulisation : verstuiwing, verneweling

\section{Afrikaans vir wrap(ping)}

Die proses waardeur veselglas om 'n plastiek- of ander pyp gedraai word om dit te versterk, word in Engels fibre glass wrapping genoem. Terblanche gee die volgende vir afleidings van wrap:

wrap v. : wikkel, omwikkel, inwikkel; toldraai wrapping n. : omhulsel; omwindsel (kabels)

Die Kernbedryfwoordeboek gee die werkwoorde omwikkel en toedraai, duidelik vir verskillende toepassings.

In die praktyk word dikwels na bogenoemde proses as oorwen verwys, met die gepaardgaande veselglasoorwenning as die selfstandige naamwoord. Het lesers dalk enige kommentaar en voorstelle in hierdie verband?

\section{SLOT}

Dit is noodsaaklik dat Afrikaanse vakterminologie nie agterbly in hierdie tye waar nuwe kennis en tegnologieë teen ' verstommende pas geskep word nie. Alle belangstellendes (nie net chemici nie!) word dus uitgenooi om bogenoemde sake in hul werkskring te debatteer en hul mening of aanbevelings te verskaf. Ons ontvang ook graag inligting oor nuwe sake wat in hierdie rubiek aan die orde gestel kan word. 


\section{Bedankings}

Die volgende persone word bedank vir hul hulp en insette:

- Die bestuur van die Afdeling Chemiese Wetenskappe, SA Akademie vir Wetenskap en Kuns.

- Dr. Laetitia den Drijver en kollegas, Departement Chemie en Biochemie, Randse Afrikaanse Universiteit.

- Dr. D.F. Louw.

- Mev. Christine Marais en kollegas, Nasionale Terminologiediens.

- Mnr. Tom McLachlan, Staatstaaldiens.

\section{LITERATUURVERWYSINGS}

I. Anon. (1995). Forum vir nuwe Afrikaanse chemieterminologie, S.Afr. Tydskr Natuurwet. Tegnol., 14, 92

2. Louw, D.F. (Red.) (1991). Die Nuwe Chemiewoordeboek (Staatsdrukker, Pretoria).

3. Louw, D.F. \& Vlok, N.V. (1985). 'n Afkortpraktyk vir Afrikaanse vakterme. S.Afr Tydskr. Natuurwet. Tegnol., 4, 4-6.

4. Afrikaanse woordelys en spelreels, agste uitgawe (1991). (Tafelberg, Kaapstad).

5. Coetzee, N., Du Plooy, N.F. \& Cluver, A.D. de V. (1985). Tweetalige Rekenaarwoordeboek (McGraw-Hill, Johannesburg)

6. Dodds, R. \& Grobbelaar, P. (1987). Rekenaarwoordeboek (HAUM, Kaapstad).

7. Louw, D.F. (1996). Persoonlike kommunikasie.

8. Kernbedryfwoordeboek, 1990 (Atoomenergiekorporasie, Pretoria).

9. Terblanche, H.J. (1976). Engels-Afrikaanse Tegniese Woordeboek (Nasou, Kaapstad).

\section{Saamstel van 'n viertalige verklarende Chemiewoordeboek}

\section{MOTIVERING}

Dit het by verskeie geleenthede onder die aandag van die Afdeling Chemiese Wetenskappe gekom dat senior sekondêre leerlinge en voorgraadse universiteitstudente wat 'n Afrikataal as huistaal het, ernstige probleme ondervind om vakke soos Chemie te bestudeer. Hierdie leerprobleme kan onder andere na die volgende oorsake teruggevoer word:

I Vakterme is in 'n hoè mate ondeursigtige en arbitrêre "etikette" vir vakkonsepte.

2 Konseptualisering binne die vak moet deur medium van 'n tweede of vreemde taal (Engels of Afrikaans) geskied omdat handboeke en ander vakliteratuur slegs in hierdie tale beskikbaar is en lesings daarin aangebied word.

3 Daar is nog nie ver gevorder met die skep van vakterminologieë vir die Afrikatale nie en vertaalekwivalente bestaan dus in die meeste gevalle nie.

4 Bestaande vakwoordeboeke is meestal slegs vertalend, aangevul deur enkele verbandswoorde.

Daar is dus 'n dringende behoefte aan verklarende én vertalende vakwoordeboeke in die natuurwetenskappe wat kan voldoen aan die behoeftes van die voorgraadse student met ' $n$ Afrikataal as moedertaal, asook Afrikaans- of Engelssprekende studente wat d.m.v. hul tweede taal studeer.

\section{DOELWITTE}

Om bogenoemde redes is onlangs begin om, as ' $n$ gesamentlike projek van die Akademie en die Universiteit van Pretoria, 'n verklarende Chemiewoordeboek in vier van die huidige amptelike tale saam te stel, naamlik Engels, Afrikaans, Sepedi (Noord-Sotho) en isiZulu.

Die keuse van Sepedi en isiZulu uit die Afrikatale kan soos volg gemotiveer word:

1 Sepedi en isizulu is verteenwoordigend van die twee hoofgroepe van die outochtone tale wat in Suid-Afrika gepraat word, naamlik onderskeidelik die Sotho-groep en die Nguni-groep.

2 In die geval van die Sotho-groep, is Sepedi ook verstaanbaar vir sprekers van bv. Sesotho (Suid- Sotho) en Tswana. Sepedi is ook die taal met die meeste normatiewe taalbronne.

3 Die Universiteit van Pretoria beskik nie oor kundiges op die terrein van isiXhosa nie, maar wel oor dosente en kundiges op die gebied van isiZulu. (Ervaring het geleer dat geografiese "fragmentering" van 'n projek remmend kan inwerk, veral in terme van die afhandelingstydperk.)

Die woordeboek sal bestaan uit ongeveer 1000 trefwoorde in Engels, met vertaalekwivalente in Afrikaans daarnaas. Indien 'n term vir die betrokke konsep reeds in Sepedi of isiZulu geskep is en 'n mate van erkenning geniet, sal dié vertaalekwivalente egter wel opgeneem word. Definisies sal in al vier die betrokke tale aangebied word om die student te help met die verduideliking en verheldering van die betrokke konsep in sy/haar moedertaal.

\section{NAVORSINGSPAN}

Projekleier: Prof. Adelia Carstens, medeprofessor in Afrikaanse Taalkunde, Universiteit van Pretoria, en lid van die Taalkommissie van die Akademie. Sy het gespesialiseerde opleiding in leksikografie ontvang en verskeie navorsings- en resensieartikels oor aspekte daarvan is reeds deur haar gepubliseer.

Medeleier: Prof. D.J. Prinsloo, professor in Sepedi, Departement Afrikatale, Universiteit van Pretoria. Hy het wye ervaring in rekenaarsagtewarepakkette en is koördineerder van die woordeboekprojek vir Noord-Sotho.

Ander medewerkers aan U.P.:

- 'n aantal studente in Afrikaans, Sepedi en isiZulu wat as onderdeel van hulle M.A.-verhandelings of skripsies aspekte van die projek sal afhandel; 
- 'n assistent met opleiding in Leksikografie wat behulpsaam sal wees met data-insameling en -verwerking;

- die Departement Chemie, wat onder andere behulpsaam sal wees met die toetsing en verifiëring van definisies en terme.

\section{VERLOOP VAN DIE PROJEK}

Die lede van die Bestuur van die Afdeling Chemiese Wetenskappe het reeds die samewerking van 'n aantal Suid-Afrikaanse tersiêre inrigtings verkry om lyste van die gebruiklikste terme, plus verklarings en vertaalekwivalente (indien beskikbaar), aan die Akademie te verskaf. Bestaande vakwoordeboeke word ter aanvulling gebruik. Soos daar gevorder word, sal die deelnemende instansies gedurig betrek word by die evaluering van terme en definisies.

Redaksionele en beleidsriglyne vir die woordeboek sal deur die projekleier in samewerking met prof. Prinsloo en ander medewerkers geformuleer word. M.A.-studente in Afrikaans het reeds begin met die sistematiese saamstel van die Engels/Afrikaanse lys en die formulering van definisies in Afrikaans en Engels. Daarna sal M.A.-studente in die Afrikatale die reeds geformuleerde definisies in Sepedi en isiZulu vertaal en, waar beskikbaar, vertaalekwivalente gee. Wanneer die manuskrip gereed is, sal dit deur proff.
Carstens en Prinsloo geredigeer en vir goedkeuring aan die taalrade/gesaghebbende taalinstansies vir Sepedi en isiZulu gestuur word. Die eindproduk sal gepubliseer, bemark en versprei word deur die Universiteit van Pretoria en die SA Akademie. Die navorsingsresultate sal ook verreken word in verhandelings en skripsies wat aan die projek gekoppel is, terwyl daar beoog word om navorsingsartikels oor verskillende aspekte van die projek in geakkrediteerde tydskrifte te publiseer.

\section{FINANSIËRING}

Ruim finansiële hulp om die projek aan die gang te kry, is reeds deur U.P. verleen. Vir die bedryfskoste word nou onderhandel met firmas in die semistaat- en privaat sektor, as toekomstige werkgewers van die studente wat die woordeboek tydens hul studies sal gebruik. Die Bestuur van die Afdeling Chemiese Wetenskappe is oortuig daarvan dat hierdie projek kan bydra om onderwysagterstande uit te wis en broodnodige wetenskaplikes, ingenieurs en tegnici aan die ny werheid te lewer. 'n Beroep word dus op Akademielede gedoen om die besonderhede van persone wat die HOPaktiwiteite van potensiële donateurs koördineer, aan die Afdeling te verskaf sodat hulle genader kan word om finansieel of andersins tot die projek by te dra. 